\title{
Church Social Doctrine contribution to Corporate Social Responsibility: a critical analysis
}

\author{
Maria Rosaria Sessa \\ Vincenzo Serpe \\ Daniela Sica \\ Ornella Malandrino \\ Department of Management \& Innovation Systems \\ University of Salerno \\ Via Giovanni Paolo II \\ 132 - 84084 Fisciano \\ (SA) - Italy
}

\begin{abstract}
The present work aims to analyse the contribution of the Social Doctrine of the Church (SDC) to the progressive and rapid evolution of the Corporate Social Responsibility (CSR) concept.

The proposal to recognise the Social Doctrine of the Church, as a valid instrument to extend the logic of corporate governance not only to the protection and respect the environment but also to the protection and respect of social welfare, is based on the idea that it is possible to do business also through the implementation of SDC principles such as solidarity, subsidiary, the universal destination of goods and the common good.
\end{abstract}

Keywords: Social Doctrine; Social Responsibility; Sustainability; Church; Enterprise

\section{Introduction}

The problematic link between ethics and business has, for years, been at the centre of wide and controversial debates both in the academic field and in business management. The relationship between ethical values and the business world is difficult to understand because there are different theories, approaches and considerations on the subject, by authoritative scholars belonging to different disciplines. The succession of conflicting reactions is probably due to at least two reasons: the substantial incompatibility between ethical values and economic fundamentals and the fact that ethical values belong to the sphere of subjective values, i.e. individual conscience. This implies two different consequences: individual relativism, for which there is the impossibility of arriving at a universally accepted truth, i.e. the definition of objective ethical principles recognized by all, and cultural relativism, for which a commonality of values and the affirmation of rational ethics is possible, since ethics is also conditioned by the principles that unite individuals in relation to the context and social role (Testa, 2007).

These currents of thought have led, over time, to the affirmation of two opposing theses: the first is based on the separation between ethical values and the economic world, while the second on the integration of these aspects.

The first concept, supported among others by authors such as Freeman (1984), is based on the assumption of the incompatibility between ethical aspects and business management, since they constitute opposing categories. It is an amoral vision of the entrepreneurial reality, arising from the conviction that the economic dimension dominates the decision-making logic and behaviour of businessmen, according to the principle of economic rationality.

Instead, the second thesis is based on the conviction that ethical values and economic performance can be integrated. In particular, some scholars (Collins and Porras, 1994) argue that those organizations capable of incorporating ethical-social objectives into their mission and translating the principles of ethics into shared values that permeate the organizational culture, will be more likely to survive in the long term (Testa, 2007). Beyond this binomial that survived until a few decades ago, today, the opinion that gives the company an ethical dimension is widely accepted, even if it is a thesis that can still arouse scepticism and bitter criticism (Manetti, 2006).

In a context such as the current one, characterized by: the important economic growth in the USA, Europe and Japan, the fragmentation of ownership, the increase in power of multinationals, the weight of the external costs of organizations, the globalization of markets and the increase in the degree of complexity of management issues, the centrality of the debate on the existence or not of a sort of Corporate Social Responsibility (CSR) is favoured. It is in this scenario that the principles of the Social Doctrine of the Church are placed, as a possible contribution to the effective realization of Corporate Social Responsibility. Therefore, the aim of the work is to investigate the role of the Social Doctrine of the Church in the field of Corporate Social Responsibility, in particular through the analysis of the project "Economy of Communion" which is based on the promotion of an economic practice and culture 
based on communion, gratuitousness and reciprocity, proposing and living an alternative lifestyle to the dominant one in the capitalist system.

\section{Corporate Social Responsibility: the reference framework}

The emergence of social changes, the spread of incorrect and fraudulent entrepreneurial behaviour, the emergence of new ideologies (which have led to an evolution of the social contract between the company and the community) and, more generally, a whole series of profound changes affecting the environmental and social context of the company, has placed the concept of Corporate Social Responsibility at the centre of scientific debate and business strategies.

The term CSR refers to the idea of a set of responsibilities that a company has towards its stakeholders, in order to ensure a fair balance between the contribution made to the organisation and the consideration received in economic and social terms. Therefore, Social Responsibility can be traced back to the inclusion of the ethical dimension in business logic and strategies.

In this regard, the countless definitions in the literature are a clear sign of the terminological disorder and uncertainty with regard to the social construction and application in a specific context of the concept of CSR (Dahlsrud, 2008).

These reasons do not fully justify the lack of a "comprehensive definition of CSR" (WBCSD, 2001), but are to be found in the difficulty of making ethical and economic aspects of corporate actions compatible. The real crux of the matter is whether the company is granted moral autonomy, since the behaviour is decided and implemented by the individuals operating within it, who can act for a variety of reasons or only out of personal interest. The possibility of choice of human action does not allow to outline a univocal and general profile of conduct in terms of CSR.

According to Carroll, the modern era of social responsibility began in the 1950s with Bowen (1953) who speaks of CSR referring to "the obligation that entrepreneurs have to pursue those policies, to make those decisions or follow those lines of action considered socially desirable in terms of objectives and values" (Bowen, 1953).

Therefore, the "social conscience" of entrepreneurs can be observed in taking responsibility for the actions taken not only in the context of economic-financial strategies but also in the social one, in order to respond to the needs of the social community of reference. This does not mean considering social responsibility as the panacea for all evils, but rather as the domain that contains an important truth, which must guide future business choices.

In the following decade, Davis (1960) was considered one of the first and most important CSR scholars of the period, as he wrote extensively on the subject and, therefore, made a significant contribution to the evolution of the concept. In particular, when he speaks of social responsibility he refers to those "decisions and actions that entrepreneurs take for reasons at least partially independent of the economic or technical interest of the company". (Davis, 1960).

Therefore, social responsibility implies greater public attention to economic and human resources and the way they are used for broad social purposes and not only in the strictly corporate interest.

Instead, in 1971, Johnson presented a series of definitions of CSR, proceeding in a critical analysis of them. In particular, he is remembered for having introduced the concept of "conventional wisdom", i.e. "a socially responsible enterprise is such when the manager balances a multiplicity of interests. Rather than only working for the large recipients of profits, it is also necessary to work for employees, suppliers, retailers, the local community and the nation" (Johnson, 1971:50). In this perspective, "corporate social responsibility is the pursuit of social and economic goals through the development of social norms in prescribed corporate roles; or simply it can be said that business management takes place in a socio-cultural system that also outlines corporate norms and roles in order to respond to particular situations and deal in detail with the way business is conducted" (Johnson, 1971:51).

In the 1980s, the focus of attention on these issues underwent a transformation: from the refined definitions of CSR to a fragmentation of writings and the promotion of alternative concepts, such as Corporate Social Responsiveness,

\section{Corporate Social Performance, Public Policy, Business Ethics and Stakeholder Theory/Management.}

It was precisely in 1980 that Jones entered, with an interesting perspective, into the discussion on CSR: the author's major contribution concerns the importance he places on CSR as a process rather than as a set of outcomes, since it is difficult to reach a unambiguous understanding of what is meant by socially responsible behaviour.

In the 1990s there were very few theoretical contributions to the definition of CSR. Rather, the concept is considered as a basis or starting point for the development of other related issues. Once again, it is relevant to present issues such as Corporate Social Performance, Stakeholder Theory, Business Ethics and corporate citizenship. 
In recent years, one of the most important contributions in this sense is that of Wood, who in 1991 proposed a CSR model based on three sections:

- levels of CSR, which include social legitimacy, public accountability and managerial discretion;

- Corporate Social Responsiveness processes, which make it possible to identify the categories for environmental assessment, stakeholder management and related problems;

- results and effects of performance, i.e. policies, programmes, practices and effects produced on stakeholders, starting from decisions taken by managers.

While, in the late 1990s, the World Business Council for Sustainable Development (WBCSD) gave its own definition of CSR, according to which CSR represents companies' commitment to contribute to sustainable economic development, in agreement with employees, their families and local communities (WBCSD, 2001).

Meanwhile, at the gates of the 21st century, the academic debate on CSR seems to take a new direction: theoretical contributions almost definitively leave the field to empirical research, which focuses mainly on investigating the relationship between CSR and Corporate Social Performance.

Just in 2000, in contrast to what was stated by the WBCSD, Piacentini et al. (2000) reinsert the characteristic of voluntariness in the exercise of CSR, beyond the economic and legal responsibilities.

In 2001, the European Commission was also part of the debate on CSR, providing its own definition of social responsibility, i.e. "CSR is a concept according to which companies integrate social and ecological issues into their business activities and relations with stakeholders" (EC, 2001).

In 2004 Sacconi, in line with what was stated by the European Commission a short time before, believes that CSR should be understood as a model of strategic management, i.e. "a model of extended corporate governance, since those who govern have responsibilities ranging from compliance with fiduciary duties towards property to similar fiduciary duties towards all stakeholders" (Sacconi, 2004).

In 2005, Kotler and Lee seek to demonstrate that the CSR approach can provide a new business model, combining business success and shareholder value creation through a respectful and proactive attitude towards stakeholders. In this regard, the authors point to six main social initiatives that could well frame CSR in the different business processes: Cause Promotion, Cause-Related Marketing, Corporate Social Marketing, corporate philanthropy, community volunteering and socially responsible business practices. The contribution of Hinna (2005) also goes in the same direction. Hinna believes that social responsibility should be considered as a necessary condition to achieve good economic performance.

It is clear from the brief definition excursus just presented that a definition of CSR has not yet been universally accepted by all the "stakeholders" in the subject: an extremely fragmented literary scenario, studded with a multiplicity of analysis perspectives and classification methodologies, continues to exist (Kotler and Lee, 2005).

Despite this, it is possible to trace a constructive aspect in the magmatic universe of definitions and metrics of CSR, shared by most of the scholars considered in this review, namely the positive influence it can have on social issues, environmental aspects and the economic activities of companies themselves.

\section{The Social Doctrine of the Church: analysis of evolutionary dynamics}

Today's socio-cultural and economic context increasingly proposes a managerial style in which the value aspect is often overshadowed, if not forgotten: a possible answer can be found in the Social Doctrine of the Church (SDC), as a useful tool to support the implementation of CSR principles.

The Social Doctrine was born with the aim of highlighting the totality of the principles, teachings and directives of the Catholic Church with the aim of taking an interest - following the canons of the Gospel - in social, political and economic problems.

The Church's concern for social problems has very ancient roots, in fact, it has been a source of discussion since the time of the Fathers of the Church and deals not only with economic problems, but also with issues related to society as a whole.

The Social Doctrine of the Church is therefore Catholic social morality and - to the extent that Catholic morality incorporates it - perfecting it, the dictation of natural morality, is social morality tout court, valid therefore not only for the believer but for all men of good will. This is how Catholic theology identifies it and how the Supreme Magisterium understands it: according to John Paul II, in fact, the Social Doctrine of the Church is "moral theology" in its own right. ${ }^{1}$

\footnotetext{
${ }^{1}$ http://www.clerus.org/clerus/dati/2000-10/12-999999/DOTTRINA.html. 
From the historical point of view, the first to deal with this theme was Pope Leo XIII with the encyclical "RerumNovarum" published on 15 May 1891.

He drew attention to the problems of the time arising from the growing gap between what was the working class and what was the master class, highlighting the growing economic disparity between them and also dealing with the relationship between capital and labour.

On May 15, 1931, for the fortieth anniversary of the "RerumNovarum", Pope Pius XI composed the "Quadragesimo Anno", in which he addressed the theme of the development of the economy perceived negatively and defined by the same: "horribly hard, inexorable, cruel". ${ }^{2}$

Later, first Pope John XXIII, with the encyclical "Mater et Magistra" of May 15, 1961, then Pope John Paul II with the "CentesimusAnnus" of May 1, 1991, dwell on the change that society has undergone in the hundred years since Leo XIII wrote the "RerumNovarum" making change and development the main theme of the encyclicals.

In particular, the encyclical "CentesimusAnnus" was a strong signal after the Soviet dictatorship and after the fall of the Berlin Wall in $1989{ }^{3}$

Between the two encyclicals, John Paul II also composed "LaboremExercens" on September 14, 1981, whose main theme is the work of man no longer seen as mere gain, but also as a form of respect for human dignity.

Continuing, in temporal order, Pope Benedict XVI, on 29 June 2009, composed the encyclical "Caritas in Veritate" in which he addressed the theme of plenary development and the universal common good alongside the spiritual and moral good of people. Pope Benedict affirms:

"The market has stimulated new forms of competition between States in order to attract production centres of foreign companies, through various instruments, including favourable taxation and deregulation of the world of work. These processes have led to the reduction of social safety nets in exchange for the search for greater competitive advantages in the global market, with serious danger for workers' rights, fundamental human rights and solidarity implemented in the traditional forms of the welfare state. Social security systems can lose the ability to perform their task, both in emerging and old developing countries, as well as in poor countries. Here budgetary policies, with cuts in social spending, often also promoted by international financial institutions, can leave citizens powerless in the face of old and new risks; this powerlessness is increased by the lack of effective protection by workers' associations. The combination of social and economic changes makes it more difficult for trade unions to carry out their task of representing workers' interests, not least because governments, for reasons of economic utility, often limit trade union freedoms or the negotiating capacity of trade unions themselves. Traditional solidarity networks thus find increasing obstacles to overcome. The invitation of the Church's social doctrine, beginning withRerumNovarum, to set up workers' associations for the defense of their rights must therefore be honored today even more than yesterday, giving above all a prompt and far-sighted response to the urgent need to establish new synergies at the international as well as the local level"4.

Finally, Pope Francis drafted the encyclical "EvangeliiGaudium" on November 24, 2013, in which he deals with fundamental issues such as the dignity and fairness of work, since they are considered by the Pontiff to be of unavoidable importance; then on May 24, 2015 he drafted the encyclical "LaudatoSì" in which he deals with the protection of the environment from the point of view of the right of all human beings to life and to an overall dignified development.

In fact, Pope Francis in the last encyclical stressed that "it is indispensable that governors and financial power look up and broaden their perspectives, that they ensure that there is worthy work, education and health care for all citizens ${ }^{5}$.

It is clear, therefore, that the various encyclicals of the Social Doctrine of the Church refer to the concept of the "common good", which can be understood as "the set of conditions of social life which allow both communities and individual members to achieve their own perfection more fully and more quickly"6; in order to do so, it must respect certain requirements deriving from the social conditions of every age, which can be traced back to the

\footnotetext{
${ }^{2}$ http://w2.vatican.va/content/piusxi/it/encyclicals/documents/hf_pxi_enc_19310515_quadragesimo-anno.html.

3 www.dottrinasociale.it/wpcontent/uploads/2014/11/04_Sintesi_Storica_DSC.pdf.

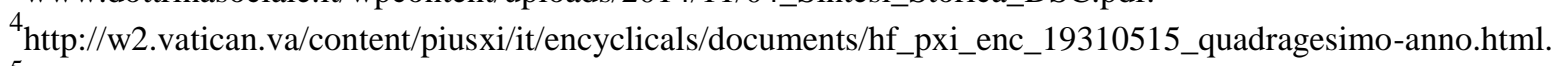

5 http://w2.vatican.va/content/piusxi/it/encyclicals/documents/hf_pxi_enc_19310515_quadragesimo-anno.html.

${ }^{6}$ Vatican Council II, Pastoral Constitution. Gaudium et Spes, 26: AAS 58 (1966) 1046; cf. Catechism of the Catholic Church, 1905- 1912; John XXIII, Lett. enc. Mater et magistra: AAS 53 (1961) 417-421; Id., Lett. enc. Pacem in Terris: AAS 55 (1963) 272-273; Paul VI, Ap. Lett. Octogesimaadveniens, 46: AAS 63 (1971) 433-435.
} 
commitment to peace, the organization of the powers of the State, but also to certain fundamental human rights such as food, housing needs, work and health.

Therefore, "the responsibility for achieving the common good lies not only with individuals but also with the State, since the common good is the raison d'être of political authority". ${ }^{7}$ Moreover, "to ensure the common good, the government of each country has the specific task of harmonizing the various sectoral interests with justice" ${ }^{8}$. This concept, brought back to the economic dimension, is to be added to the "moral good" which considers economic efficiency and the promotion of a development in solidarity of humanity as two inseparable and no longer separable goals.

The aim of economic performance, taking this concept into account, is to achieve wealth not only in quantitative but also qualitative terms, i.e. the development of the human being and the society in which he lives and works. That said, the Church's Social Doctrine recognizes the freedom of the person from the economic point of view and considers it a fundamental value and an inalienable right to be promoted and protected, so that "everyone has the right of economic initiative; everyone will legitimately use his or her talents to contribute to an abundance from which all can enjoy, and to reap the right fruits from his or her efforts"'.

The company, in the production of goods and services, must focus on those products that are able to generate efficiency and satisfy the interests not only of entrepreneurs but also of all its stakeholders, precisely from the perspective of Corporate Social Responsibility.

In fact, the economic dimension must be flanked by the social and moral dimension because the company creates opportunities for meeting, collaboration and enhancement of the community's capabilities: "The company cannot be considered only as a corporation; it is, at the same time, a partnership, of which both those who provide the capital needed for its activity and those who collaborate with their work are part in a different way and with specific responsibilities ${ }^{10}$.

\section{The SDC as a possible instrument of CSR: the Economy of Communion (EOC)}

It is within the notions of moral good and social good that the concept of "Economy of Communion" was defined in May 1991 in São Paulo, Brazil, by Chiara Lubich - founder and first president of the Focolare Movement - as a management model capable of involving entrepreneurs, workers, managers and all individuals engaged at various levels of the enterprise in promoting the centrality of the human being.

The idea was born when the Italian activist and essayist Lubich met a Brazilian community that, in the 1990s, was dramatically affected by the disparity and social contrast between the very rich few and the millions of very poor individuals, but also as a response to the encyclical "CentesimusAnnus", in which the social, economic and political situation of that time was clearly presented, as Chiara Lubich herself ascertained during her meeting with the Brazilian community.

Therefore, on 29 May 1991 Chiara Lubich spoke to Araceli: "In these days we have come to consider the social aspect present in our charism. A charism that certainly has many aims: that leads to holiness, to a new evangelization, to ecumenism, to building peace [...] but that also helps to resolve the social problem [...] because it underlines a social economic reality: the communion of goods. And not only does it make its necessity felt, but it has been implemented in the Movement for 47 years in different forms [...] It is a practice, this of the communion of goods, which is particularly dear to us and is, I would like to say, a new element. Every charism, in fact, that emerges in the Church, brings a newness that is implicit in Sacred Scripture and in the constant teaching of the Church, but that the Holy Spirit makes explicit in its time. We have made explicit how congenial to the Christian life the communion of goods is [...] If the whole world were to implement it, social inequalities, the poor, the hungry, the dispossessed [...] would no longer exist [...] For our part, during these years, we have enriched this experience with all the contributions that the social doctrine of the Church has offered, above all through the social encyclicals... Now here in Araceli an idea has been born: That God call our Movement in Brazil, which counts about 200,000 people with sympathizers, to implement a wider communion of goods, that engages the whole Movement as a whole [...] These companies, of various types, should be supported by people from all over Brazil; societies should be born where everyone has the possibility of their own participation: even modest, but very

\footnotetext{
${ }^{7}$ See Catechism of the Catholic Church, 1910.

${ }^{8}$ See Catechism of the Catholic Church, 1908.

${ }^{9}$ Catechism of the Catholic Church, 2429; cf. Vatican Council II, Pastoral Constitution. Gaudium et spes, 63: AAS 58 (1966) 1084-1085; John Paul II, Lett. enc. CentesimusAnnus, 48: AAS 83 (1991) 852-854; Id., Lett. enc. Sollicitudo rei socialis, 15: AAS 80 (1988) 528-530; Id., Lett. enc. Laboremexercens, 17: AAS 73 (1981) 620-622; John XXIII, Lett. enc. Mater et magistra: AAS 53 (1961) 413-415.

${ }^{10}$ John Paul II, Enc. Lett. CentesimusAnnus, 43: AAS 83 (1991) 847. 
widespread participations. The management of these companies should be entrusted to capable and competent elements, able to make these companies work with the maximum efficiency and obtain profits from them [...] And here lies the novelty that these profits should be pooled [...] An economy of communion of which this citadel would constitute a model, a pilot city [...] Unlike the consumerist economy, based on a culture of having, the economy of communion is the economy of giving. This may seem difficult, arduous, heroic. But it is not so because man, made in the image of God, who is Love, finds his realization precisely in loving, in giving. This need is in the depths of his being, whether he is a believer or not. And it is precisely in this observation, supported by our experience, that lies the hope for a universal diffusion of the economy of communion ${ }^{11}$.

As can be seen from the words of the founder of the Focolare Movement and from the programs that she herself has put into practice over time, the model thus conceived is based on an economic culture marked by communion, gratuitousness and reciprocity, contrasting the demands of the capitalist system.

In particular, the "Economy of Communion" is based on certain fundamental principles, such as:

- $\quad$ living and spreading a new economic and civil culture, from children to the elderly, called "culture of giving";

- $\quad$ train new entrepreneurs and new entrepreneurs who freely share the profits to support the aims of the new approach: reducing poverty/exclusion, spreading the culture of giving and communion, business development and job creation. Therefore, entrepreneurs who conceive and live their business as a vocation and service to the common good and to the excluded of all latitudes and social contexts;

combat the various forms of poverty, exclusion and misery with a dual inclusion: community and productive.

Therefore, according to Chiara Lubich "it is not possible to cure any form of unchosen poverty without including disadvantaged people within living and fraternal communities, and, where possible, even in the workplace, in businesses: as long as those who can and must work are unable to have the opportunity, they always remain a destitute person. ${ }^{12}$

These principles have been widely accepted and shared in many European and non-European countries: Brazil, Argentina, Italy, Croatia, Belgium and Portugal, through the creation of countless "industrial poles" aimed at the realization of the "Economy of Communion", considered an innovative approach able to positively influence the development and progressive evolution of the concept of Corporate Social Responsibility.

In particular, in the last five years, about 900 organizations in the world have decided to adopt the EoC approach and, therefore, have joined one of the five industrial poles in Europe and outside Europe.

\subsection{From the Economy of Communion to the Sharing Economy}

When in 1991 Chiara Lubich took her first steps towards the realization of the EoC, the academic and nonacademic world began to take an interest in the theme and, at the same time, to feel part of that project.

In particular, LuiginoBruni - university professor and active member of the movement for the diffusion of the "Economy of Communion" - is one of the greatest promoters of this approach in the managerial field.

According to Bruni, the aim of the "Economy of Communion" is to "reform capitalism, and therefore its main institution: the enterprise $[\ldots]^{13}$.

It is, therefore, necessary to translate the principles of this approach into concrete actions capable of adapting to the current socio-economic and cultural reality, in which the frontier of Corporate Social Responsibility is clearly visible. "Social business has become a varied, dynamic and constantly growing movement. The so-called Sharing Economy is giving life, all over the world, to very innovative experiences [...] sharing the profits of companies in favour of poor and young people was in itself an innovation"14.

The problem of the obsolescence of the "Economy of Communion" - resulting from the evolution of the economic, social, environmental and cultural context - finds in the concept of Sharing Economy a possible solution, since it is a step consistent with the evolution of the relationship between market and society.

In an attempt to define this phenomenon, it is meanwhile possible to attribute to the concept of Sharing Economy all those activities for which the following characteristics are found, in a different way:

- the market coexists with some dimension of gratuitousness (of time, energy, money);

- contracts are intertwined with relational goods;

\footnotetext{
11 https://www.cittanuova.it/leconomia-di-comunione-nel-pensiero-di-chiara-lubich/.

12 http://www.edc-online.org/it/chi-siamo/che-cose.html.

$13 \mathrm{https}: / /$ www.cittanuova.it/leconomia-di-comunione-ha-25-anni/.

14 https://www.cittanuova.it/leconomia-di-comunione-ha-25-anni/.
} 
- $\quad$ the exchange stems from an explicit and intentional mutual benefit.

Therefore, this economic model no longer favours mere profit, but starts from the real needs of consumers. Reuse, re-use and sharing have, in recent years, become the priorities of many national and international business realities that use innovations to create a circular economy, within which professionals, consumers and ordinary citizens make their skills, time, goods and knowledge available for the creation of virtuous links.

This promotes new lifestyles that favour the reduction of costs and the redistribution of financial resources, favouring socialization and the protection of the surrounding environment.

\section{Concluding remarks}

The continuous changes in the socio-economic scenario, due to a multiplicity of factors, which are becoming increasingly important both internationally, due to the global dimension of some phenomena, and at regional and local level, due to the urgent need to identify production and consumption models capable of reconciling economic development and protection of the natural and social environment within the different socio-cultural and institutional contexts, have imposed a rethinking of corporate strategies, with a view to increasing sustainability.

It is precisely in this context that the concept of CSR is placed, which, although it does not have a particularly recent evolutionary history, today assumes great importance within the managerial logic of the organization, which are called to respond to the needs of a multiplicity of stakeholders, through the overcoming of the traditional economic approach, based on the maximization of economic welfare, in order to include further objectives aimed at environmental protection, the enhancement of natural resources as well as equity, solidarity and social cohesion.

CSR's statement therefore defines a more demanding role for the business world, hence a rethinking of the very goals that companies are called upon to pursue.

The brief historical and theoretical excursus on the evolution of the concept of Social Responsibility proposed well highlights the limits of the reflections associated with this issue, including the difficulty of recognizing in human capital, the dimension that contributes most to increasing the competitive advantage of CSR-oriented organizations.

This difficulty can partly be solved through the use of a variety of tools, such as: the Code of Ethics, the Social Report, the Sustainability Report and many other voluntary non-financial reporting tools, which have the ability to formalize and consolidate the ethical values common to the entire organizational system. However, many of the above mentioned Corporate Social Responsibility tools may not be very effective if not adequately supported by others.

In this regard, the SDC, through the analysis of the various encyclicals and, even more so, of the "Economy of Communion" approach proposed by Chiara Lubich, can be recognized as an appropriate tool to implement the principles underlying Corporate Social Responsibility and, therefore, to implement socially sustainable management strategies.

\section{References}

Bowen, H.R., (1953). Social responsibilities of the businessman, Harper \& Row, New York, NY, p.6.

Bruni, L., (2016).L'Economia di Comunione ha 25 anni, https://www.cittanuova.it/leconomia-di comunione-ha-25anni/ (last accessed: 27.01.2020).

Catechismo della Chiesa Cattolica. http://www.vatican.va/archive/ccc_it/ccc-it_index_it.html(last accessed: 27.01.2020).

Collins, J.C. and Porras, J.I. (1994). Built to Last: Successful Habits of Visionary Companies, 21 Century, London.

Comunicazione della Commissione Europea, (2001). Realizzare uno spazio europeo dell'apprendimento permanente, Novembre 2001, Bruxelles. https://archivio.pubblica.istruzione.it/dg_postsecondaria/allegati/apprperm211101.pdf.

Congregazione per ilClero.http://www.clerus.org/clerus/dati/2000-10/12-999999/DOTTRINA.html(last accessed: 22.01.2020).

Dahlsrud, A., (2008). "How Corporate Social Responsibility is Defined: an Analysis of 37 Definitions", Corporate Social Responsibility and Environmental Management, Vol. 15, No.1, pp. 1- 13.

Davis, K., (1960). "Can business afford to ignore social responsibilities?”, in California Management Review, Vol. 2, No. 3, 70-76, p.70.

Dottrina Sociale.www.dottrinasociale.it/wp-content/uploads/2014/11/04_Sintesi_Storica_DSC.pdf (last accessed: 22.01.2020).

Economia di Comunione. http://www.edc-online.org/it/chi-siamo/che-cose.html (last accessed: 27.01.2020). 
Freeman, R.E., (1984).Strategic Management: A Stakeholder Approach, Prentice-Hall, Englewood Cliffs, NJ.

Giovanni Paolo II, (1991). https://w2.vatican.va/content/john

paulii/it/encyclicals/documents/hf_jpii_enc_01051991_centesimus-annus.pdf (last accessed: 27.01.2020).

Hinna, L., (2005).Come gestire la responsabilitàsocialedelleimprese, IlSole24Ore, Milano.

Johnson, H.L., (1971).Business in contemporary society: Framework and issues, Wadsworth, Belmont, CA, pp.5051.

Jones, T.M., (1980). "Corporate social responsibility revisited, redefined", California Management Review, Vol. 22, No. 3, pp. 59- 67.

Kotler, P., Lee, N. (2005).Corporate Social Responsibility: doing the most good for your company and your cause, Wiley, Hoboken, N.J.

Manetti, G., (2006).Il Triple Bottom Line. Dal coinvolgimento degli stakeholder alle verifiche esterne, FrancoAngeli, Milano.

Piacentini, M.G., MacFadyen, L. and Eadie, D.R. (2000). "Corporate social responsibility in food retailing", International Journal of Retail and Distribution Management, Vol. 28, No.10, pp. 459-469.

Quartana, C., (2012).L'Economia di Comunione nel pensiero di Chiara Lubich, https://www.cittanuova.it/leconomia-di-comunione-nel-pensiero-di-chiara-lubich/ (last accessed: 27.01.2020).

Sacconi, L. (2004). "Responsabilità Sociale come Governance allargata d'impresa: un'interpretazione basata sulla Teoria del Contratto Sociale e della Reputazione", in Rusconi, G. and Dorigatti, M. (Eds.), $L a$ responsabilità sociale d'impresa, FrancoAngeli, Milano, pp. 107- 152.

SantaSede.http://w2.vatican.va/content/pius-xi/it/encyclicals/documents/hf_pxi_enc_19310515_quadragesimoanno.html (last accessed: 22.01.2020).

Testa, M., (2007).La responsabilità sociale d'impresa. Aspetti strategici, modelli di analisi e strumenti operativi, Giappichelli Editore, Torino.

WBCSD, (2001). The greenhouse gas protocol: a corporate accounting and reporting standard, Geneva WBCSD / World Resources Institute, Geneva.

Wood, D., (1991). "Corporate social performance revisited", Academy of Management Review, Vol. 16, No. 4, 691718. 